\title{
The Ebullient Transhumanist and the Sober Theologian
}

\section{TED PETERS"}

Center for Theology and the Natural Sciences at the Graduate Theological Union, Berkeley CA, USA

tedfpeters@gmail.com

ORCID: 0000-0002-2148-5858

\begin{abstract}
The worldwide transhumanist $(\mathrm{H}+)$ movement upgrades technological hopes and expectations to a level of spiritual fervor. When looking through the eyes of the public theologian, we see in $\mathrm{H}+$ a disguised religion replete with faith in techno-salvation and even immortality. This is unrealistic. Whereas $\mathrm{H}+$ assumes enhanced intelligence has redemptive power, the more realistic theologian avers that it is love and love alone that has transformative power. The implicit Gnostic assumptions of $\mathrm{H}+$ are too weak to redeem the human condition; they need fortification by a hard-nosed sinand-grace dialectic. Apologetic public theologians can offer the wider public a more realistic assessment of technology's potential while providing genuine hope in a future vision based on divine promise.
\end{abstract}

Keywords: Artificial Intelligence; Intelligence Amplification; transhumanism; $\mathrm{H+}$; superintelligence; Singularity; radical life extension; cybernetic immortality; Gnosticism; public theology; love; sin-and-grace.

Ted Peters (Ph.D., University of Chicago) teaches systematic theology at the Graduate Theological Union in Berkeley, California, USA. He co-edits the journal, Theology and Science, at the Center for Theology and the Natural Sciences. He is author of God--The World's Future (Fortress, 3rd ed., 2015) and co-author of Evolution from Creation to New Creation (Abingdon 2002). Along with two colleagues he is editing a new book, Religious Transhumanism and its Critics (Lexington). He is author of a fiction thriller with a Transhumanist plot, Cyrus Twelve, with Aprocryphile Press. Visit his website: TedsTimelyTake.com. 


\section{Introduction}

What kind of question does transhumanism prompt the theologian to ask? Is it an anthropological question, asking just what is human nature? Is it an eschatological question, asking how radical life extension (RLE) or cybernetic immortality compare to Christian eschatology? Is it an ethical question, asking whether it is moral to sacrifice Homo sapiens on the altar of extinction on behalf of a surviving superintelligent species? Or, is it a cultural question, asking whether science along with technology should supersede religion in setting society's goals and grounding its values?

If theologians have been asleep during our era of scientific and technological revolution, it is time to wake up. The alarm is sounding. Here is the morning news: technoscience is running for the office of messianic savior. Jesus Christ has a new rival in the form of Transhumanism (also known as $\mathrm{H}+$ or Humanity Plus). The transhumanists are excited, even ebullient, about the prospect of human transformation, cyborg superintelligence, freedom from bodily suffering, and even immortality. If $\mathrm{H}+$ wins the hearts and minds of the populace, theologians will become obsolete. Theologians could be replaced by a techno-priesthood liturgically garbed in jeans, tee shirts, and ear buds.

Like climbing the Tower of Babel, the techno-priests among us promise a self-transformation that will catapult the mere human into the realm of the divine. „Having raised humanity above the beastly level of survival struggles, we will now aim to upgrade humans into gods, and turn Homo sapiens into Homo deus" (Harari, 21).

Jesus warned us: "Beware of false prophets, who come to you in sheep's clothing but inwardly are ravenous wolves" (Matthew 7:15). Does Jesus' warning apply to $\mathrm{H}+$ ? Are transhumanists really ravenous wolves in sheep's clothing? No and yes. Some transhumanists are compassionate and charitable, while others belligerent and totalitarian. On the one hand, Hank Pellissier, who directs the non-profit charity Brighter Brains Institute (Brighter Brains), supports education and medical care for marginalized children in Africa, Peru, and Bangladesh. On the other hand, Founder of the 
Transhumanist Party in the USA and former presidential candidate, atheist Zoltan Istvan, is blatantly hostile to religion: "A nation that promotes reason has no business including God in the public sphere" (Istvan). Nevertheless, both types of transhumanists are visionary. Dedicated. Smart. Therefore, theologians should follow St. Paul's advice to "discern what is the will of God--what is good and acceptable and perfect” (Romans 12:2).

I recommend that today's public theologian ask questions stimulated by transhumanism such as this: how do we de-colonize the hegemony that technology now enjoys in the global economy and culture? What the theologian should discern is how transhumanism has upgraded technology into a religion replete with anthropology and soteriology. Minds too invested in the $\mathrm{H}+$ promise may be drawn into a set of unrealistic expectations and frustrated hopes. To de-colonize and de-spiritualize transhumanism, the public theologian should offer sober and realistic talk in the wider society.

Quite specifically, $\mathrm{H}+$ assumes that the telos within progressive evolution incarnates an ongoing spiral toward increased intelligence. Transhumanists then prophesy that the superintelligent posthuman will inaugurate utopia. The public theologian, in contrast, will likely assert that the dialectic between sin-and-grace more realistically describes the human condition, relying on God's promise rather than technological enhancement for redemption.

\section{From Enhanced Humans to Intelligent Machines}

"Transhumanism... is an interdisciplinary approach to understanding and evaluating the ethical, social and strategic issues raised by present and anticipated future technologies," avers Oxford's Nick Bostrom. “The focus is especially on those technologies that either pose a threat to the survival of the human civilization, or, in contrast, promise to create opportunities for overcoming fundamental human limitations" (Bostrom). The key to overcoming those limitations is enhanced intelligence.

We in the species Homo sapiens have already become enhanced by various technologies. Our cell phones have already enhanced the human self, so that each of us is becoming increasingly a digitized extended self. 
The border between our autonomous self and those accessing and being influenced by our thoughts is dissolving through our bio-electro-psycho connection to the internet. Our phones, our smart watches, our iPads and such have become an intimate part of who we are becoming. Digital devices are intimate not only in the sense that they are connected to our body, but in the sense that we tie our very psyches to them. We sleep with them, we wake up with them, and "the air we breathe is filled, in both a literal and figurative sense, with the trails of ones and zeros that these devices leave behind" (Lynch).

Our symbiosis with technology will only increase in coming years (Investopedia; Kwon; Russell).

The coming years will usher in a number of body augmentation capabilities that will enable humans to be smarter, stronger, and more capable than we are today... In the future, we can expect the arrival of contact lenses that can take pictures or video, universal language translator earbuds that allow us to communicate anywhere in the world, and exosuits that increase physical strength. We will also see increased use of implants ranging from brain microchips and neural lace to mind-controlled prosthesis and subdermal RFID chips that allow users to unlock doors or computer passwords with the wave of a hand. However, the most powerful body augmentation will come from biological augmentation as a result of increased insight into our genomes, advances in IVF technology that may allow us to select the most intelligent embryos, and powerful CRISPR gene-editing technology which may one day give us the ability to eliminate all heritable diseases. (Singh)

This march of human enhancement could lead to the evolution of the posthuman, at least according to the transhumanists. Posthuman refers to "a person who can co-exist in multiple substrates, such as the physical world as a biological or semi-biological being. The future human... will live much longer than [today's] human and most likely travel outside the Earth's orbit" (Vita-More, 31). The trans in transhumanism conscripts today's movement into creating the posthuman. Transhuman refers to a class of... 
philosophies of life that seek the continuation and acceleration of the evolution of intelligent life beyond its currently human form and human limitations by means of science and technology, guided by life-promoting principles and values... Transhumanists regard human nature not as an end in itself, not as perfect, and not as having any claim on our allegiance. Rather, it is just one point along an evolutionary pathway and we can learn to reshape our own nature in ways we deem desirable and valuable. By thoughtfully, carefully, and yet boldly applying technology to ourselves, we can become something no longer accurately described as human - we can become posthuman. (More)

Let's look more closely at the matter of intelligence enhancement as a step from the human to the posthuman. Imagine a computer chip surgically implanted within your brain that would give your mind immediate access to all the knowledge in Encyclopedia Britannica. Or, better, Wikipedia with daily updates electronically sent to your brain from a satellite. This kind of enhancement is called Intelligence Amplification (IA). Whether increased access to information constitutes intelligence remains to be proven, to be sure; yet, IA is on the drawing board.

Much easier to imagine is Artificial Intelligence (AI) in a robot which vacuums your living room carpet. What is AI? Ask someone who sells products purported to be intelligent. „Artificial intelligence (AI) is a term for simulated intelligence in machines. These machines are programmed to 'think' like a human and mimic the way a person acts. The ideal characteristic of artificial intelligence is its ability to rationalize and take actions that have the best chance of achieving a specific goal, although the term can be applied to any machine that exhibits traits associated with a human mind, such as learning and solving problems" (Investopedia). Although not human, AI thinks „like a human.” Further, this thinking takes place in a machine, not in a human.

Is AI really intelligent? Not yet. If we use human intelligence as the measure, to date no AI can match it. „Robots that can develop humanlike intelligence are far from becoming a reality... [AI] still belongs in the realm of science fiction" (Kwon, 31). No computer to date can handle the equivocal or multivalent meanings of words requiring context to interpret. Nor can 
any computer leap to insight. There is nobody home in a computer: no sense of self; no agency; no setting of goals or embracing of values. The human bar is too high for even superior machine calculation.

Important for our discussion here is to note how the measure of intelligence for technophiles is human intelligence, not some sort of sui generis machine intelligence. Oh yes, machines can calculate faster than the human brain. Oh yes, machines can engage in deep learning through synthesizing algorithms with feedback loops. Oh yes, machines can do marvelous things. But, should they be called intelligent? No. „We do not yet have intelligent computers," contends Noreen Herzfeld, a computer scientist and theologian. „We may never have them” (Herzfeld, 94).

The matter of getting right on what counts as intelligence is important when we move from the human to the posthuman. Exactly how to define the posthuman, is not yet clear. „Thus, the posthuman is not any one particular thing; it is an act of projection, of speculation about who we are as human beings, and who we might become" (Kull, 297). Yet, one thing is for certain: this transition--this evolution from the human to the posthuman via the transhuman--involves enhancing intelligence. Transhumanists anticipate a giant leap forward to superintelligence, to a level of AI or IA far superior to what the human race to date has experienced. To cross the threshold from the human to the posthuman where superintelligence takes over the reins of our evolutionary future is called the Singularity. To the Singularity we now turn.

\section{From Intelligence to Superintelligence via the Singularity}

The term, Singularity, as used among transhumanists, differs from its use in Big Bang cosmology. For computer innovator Ray Kurzweil, the Singularity is a dramatic future event expected about the year 2045. This will be a threshold event. Once we have crossed this threshold, artificial intelligence will become self-replicating superintelligence. This posthuman intelligence will take over civilization.

What some call the intelligence ratchet begins with the creation of the first machine more intelligent than we humans are. That machine will then 
takeover procreation, so to speak, to create a machine more intelligent than it is. And so on. We will quickly cross the Singularity threshold where machines control the future evolution of intelligence as well as everything else (Levy, 20).

How do we get there from here? Through rapid technological advance. The front engine pulling the train will be enhanced human intelligence. What follows this lead is the observation that human intelligence will leap from human bodies to machines, making high tech machines more human than we are. What we call whole brain emulation--moving our mind out of our body and into a computer--can happen allegedly because intelligence is not dependent upon our biological substrate. Rather, as information in patterns, intelligence can be extricated from our bodies. Our intelligence can live on in an enhanced form even when extricated from our bodies and placed in a computer. "Uploading a human brain means scanning all of its salient details and then reinstantiating those details into a suitably powerful computational substrate. This process would capture a person's entire personality, memory, skills, and history" (Kurzweil, 198).

On the one hand, this would require disembodied intelligence. On the other hand, we would have new bodies, namely, machines. "Future machines will be human even if they are not biological," writes Kurzweil. "This will be the next step in evolution" (Kurzweil, 199). Still human? Really?

Or, would it be more accurate to say that superintelligence living in a computer cloud would be posthuman? Especially when we observe how $\mathrm{H}+$ relies on progressive evolution to ground its futurist vision.

Some in the $\mathrm{H}+$ camp envision the posthuman as divine, as a god.

Techno-humanism agrees that Homo sapiens as we know it has run its historical course and will no longer be relevant in the future, but concludes that we should therefore use technology in order to create Homo deus-a much superior model. Homo deus will retain some essential human features, but will also enjoy upgraded physical and mental abilities... Since intelligence is decoupling from consciousness, and since non-conscious intelligence is developing at breakneck speed, humans must actively upgrade their minds if they want to stay in the game.” (Harari, 357) 
All aboard Harari's express train from Homo sapien to Homo deus via technological progress!

When discerning the spirit of $\mathrm{H}+$, the public theologian should become concerned about two assumptions. First, the highest value on the $\mathrm{H}+$ scale is intelligence. Superhumanity will be superintelligent, accordingly. For the theologian, in contrast, the highest value is not intelligence. Rather, it is love. Increased intelligence would be quite capable of increasing the destructive force of evil. Increased love, regardless of its accompanying level of intelligence, increases compassion, peace, and harmony. Love is redemptive.

Second, the transhumanists make a questionable assumption regarding the intrinsic role of progress within evolution. To that assumption we now turn.

\section{Is Evolution Really Progressive?}

How do transhumanists philosophically ground their optimism about the future? They appeal to the doctrine of progress embedded in evolution. Because evolution is allegedly progressive, we can have confidence that today's human will be superseded by tomorrow's posthuman.

$\mathrm{H}+$ thanks our evolutionary past for bringing us to the point of intelligence. Now, we the human race must move still further forward. Our generation has the opportunity to enhance our intelligence, to advance still further in evolutionary development. Computers along with GNR-genetics, nanotechnology and robotics-are all tools whereby we can build a dramatically new future for abundant living and cosmic community.

Kurzweil, like most in the $\mathrm{H}+$ movement, conflates biological evolution with technological progress. He sees the latter as an extension of the former. Both natural evolution and human technology benefit from a guiding purpose, a built-in purpose, an inner telos. And this built-in telos or entelechy virtually guarantees the future he is forecasting. Simon Young makes this explicit, "The furtherance of human evolution through advanced biotechnology is not only possible, but inevitable" (Young, 22).

What is this built-in purpose? Increased intelligence. 
The purpose of the universe reflects the same purpose as our lives: to move toward greater intelligence and knowledge... we will within this century be ready to infuse our solar system with our intelligence through self-replicating non-biological intelligence. It will then spread out to the rest of the universe. (Kurzweil, 372)

Our earth-bound past will be superseded by a posthuman machine intelligence spreading through space to the cosmos.

Tomorrow's leap from Earth to outer space requires us today to apply our existing intelligence to leap the hurdles that confine us. The technology of whole brain emulation will spring us forward. "Insight from the brain reverse-engineering effort, overall research in developing AI [Artificial Intelligence] algorithms, and ongoing exponential gains in computing platforms make strong AI (AI at human levels and beyond) inevitable. Once AI achieves human levels, it will necessarily soar past it because it will combine the strengths of human intelligence with the speed, memory capacity, and knowledge sharing that nonbiological intelligence already exhibits" (Kurzweil, 407). Note Kurzweil's confident vocabulary: "inevitable" and "necessary." It's progressive evolution that is propelling the transhuman toward the posthuman.

\section{Salvation from the Environmental Crisis}

Transhumanists are utopians. Technological progress provides the key to salvation. Beyond maximized intelligence, the $\mathrm{H}+$ messiah will also bring ecological harmony. Most transhumanists embrace technogaianism, an ethic for technology that supports the Gaia philosophy.

Kurzweil, for one, believes that nanotechnology will rescue us from our environmental crisis. By building devices at the molecular scale out of nanoparticles, we could reduce the size and surface area of such devices, lowering their impact on the surrounding environment. In addition, new biological properties will be introduced, so that nanotechnology "will eventually provide us with a vastly expanded toolkit for improved catalysis, 
chemical and atomic bonding, sensing, and mechanical manipulation, not to mention intelligent control through enhanced microelectronics. Ultimately we will redesign all of our industrial processes to achieve their intended results with minimal consequences, such as unwanted by-products and their introduction into the environment" (Kurzweil, 251).

According to this vision, manufacturing in the future would do less damage to our environment. In addition, we would develop better methods of cleaning up pollution. And we would even overcome hunger and poverty. "Emerging technologies will provide the means of providing and storing clean and renewable energy, removing toxins and pathogens from our bodies and the environment, and providing the knowledge and wealth to overcome hunger and poverty" (Kurzweil, 371-372). Nanotechnology in the service of progress could lead today's world into a tomorrow of social justice and ecological harmony. The public theologian must grant, I believe, that this is an ebullient, high-minded, and noble vision.

Nevertheless, Reinhold Niebuhr, along with other neo-orthodox theologians so profoundly affected by the technologized destruction of two world wars, warned us against self-flattering utopiansim. "Against utopianism the Christian faith insists that the final consummation of history lies beyond the conditions of the temporal process. Against other-worldliness it asserts that the consummation fulfills rather than negates the historical process" (Niebuhr, 2:291). This is sober Christian realism. In my judgment, Christian prophets should hold up before society a vision of a utopian future that provides a goal, goad, and ground for moral transformation. Yet, Niebuhr rightly warns us to be realistic about what we can and cannot accomplish as sinful human beings apart from divine grace.

\section{The Promised Technological Victory over Aging and Death}

Like St. George slaying the dragon, our $\mathrm{H}+$ heroes are arming to fight the most powerful enemy of the human race, namely, death. To rid us of this most feared of all enemies, $\mathrm{H}+$ knights are donning two different weapons: radical life extension (RLE) and cybernetic immortality (Peters, 2009; 2010; 
2011, 2018c). The first is biological, while the second is postbiological (Peters, 2016; 2018c).

\subsection{Radical Life Extension}

Leading us into the RLE battle is Aubrey de Grey. Even though de Grey is reluctant to call himself a transhumanist because he wants to enhance what is already human, he is dedicated to immortality. If we could eliminate aging, then "we will be in possession of indefinite youth. We will die only from the sort of causes that young people die of today-accidents, suicide, homicide, and so on-but not of the age-related diseases that account for the vast majority of deaths in the industrialized world today" (de Grey, 2016). Improvements in rejuvenation technology will move quickly, forecasts de Grey, measured by LEV or "longevity escape velocity" (de Grey, 2009, 21). Soon “the average person... can expect to live at least 1,000 years" and the human race for billions of years (de Grey, 2009, 22). Now, we might ask: might this be realistic?

Until recently demographers assumed that once gains made by reducing mortality in early and mid life had reached completion, then growth in longevity would level off and we would see a fixed maximum for human age. However, to our surprise, this is not happening. In much of the developed world, life expectancy continues to increase; and people reach old age in healthier condition than their grandparents did. Might realism be on the side of the transhumanists?

Why do we grow old? Can we do something about it? "Clear consensus now exists that ageing is caused by the gradual, lifelong accumulation of a wide variety of molecular and cellular damage. At the heart of the genetic determination of lifespan is the extent to which the organism's genome invests in survival." With the many tasks genetic expression needs to perform, why waste time and energy on repairing what is broken in order to lengthen the life span of the host organism? Can we edit our genes to patch up breakdown and work for constant enhancement? Might we intervene to patch up molecular and cellular damage while turning on those genes that enhance human potential? Yes. "If ageing is a matter of things falling apart, 
can research realistically hope to achieve anything useful? The answer is emphatically yes-there is plenty of evidence that it is possible to intervene in the underlying causative mechanisms" (Kirkwood, 645).

\subsection{Cybernetic Immortality}

That's RLE. What about cybernetic immortality via whole brain emulation? Let's return for a moment to Kurzweil. According to the cybernetic immortality scenario, humans of a future generation will rely upon a machine substrate. From the machine our consciousness can escape into the computer cloud.

When we have escaped our biological limitations, we will be able to program a much longer life, a disembodied digitized life. "The Singularity will allow us to transcend these limitations of our biological bodies and brains. We will gain power over our fates. Our mortality will be in our own hands. We will be able to live as long as we want... By the end of this century, the nonbiological portion of our intelligence will be trillions of trillions of times more powerful than unaided human intelligence" (Kurzweil, 9).

Is the prospect of living in cyberspace attractive? One would not be alone. One's cybermind would be in community with all other cyberminds, a variant on Teilhard's noosphere. One might even celebrate a new higher level of community. This is what Margaret Wertheim celebrates. Despite the dangers lurking in our computers, she thanks cyberspace for establishing a network of relationships. Further, the global community of electronic relationships is eliciting a sense of responsibility toward one another. "If cyberspace teaches us anything," writes Wertheim, "it is that the worlds we conceive... are communal projects requiring ongoing communal responsibility" (Wertheim, 304). Once Kurzweil has successfully uploaded our minds into cyberspace, we will enjoy a communal network of shared intelligence.

Ray Kurzweil offers an ebullient version of this otherwise cautious forecast: "We are beginning to understand aging, not as a single inexorable progression but as a group of related processes. Strategies are emerging for fully reversing each of these aging progressions, using different combina- 
tions of biotechnology techniques" (Kurzaweil, 212-213). With emphasis Kurzweil trumpets, "We have the means right now to live long enough to live forever" (Kurzweil, 371).

\section{De-Centering the Human Body? Really?}

Living forever Kurzweil style in a digitized consciousness located in the computer cloud looks somewhat like the premodern notion of the disembodied soul. Curiously, twenty-first century theologians are hanging on to their bodies just when transhumanists are ready to get rid of them.

Philosophical theologian Adam Pryor assess the de-centering of the human body within a postmodern framework. „The important point here is that if we think deeply through the implications of hybridity in the cyborg, then human bodies are decentered. The stable, fixed notion of a natural body separate from its world, bounding what is legitimately me (subject) as distinct from everything else (object), is antiquated in light of the posthuman" (Pryor,15).

Not everyone leaps up to applaud this techno-promise of an everlasting disembodied life. Jewish scholar, Hava Tirosh-Samuelson, objects vehemently to the messianic plan of $\mathrm{H}+$ to supersede humanity. „I reject transhumanism because it calls for the planned obsolesce of the human species on the grounds that biological humanity, the product of a long evolutionary process, is not only an imperfect work in progress but a form of life inherently flawed and that has no right to exist" (Tirosh-Samuelson, 203, author's italics). She wants to keep her body.

Similarly, a Christian, Brian Alexander, objects to the idea of disembodied immortality because he too wants to keep his body. "Modern transhumanism is a statement of disappointment. Transhumans regard our bodies as sadly inadequate, limited by our physiognomy, which restricts our brain power, our strength and, worst of all, our life span. Transcendence will not be found in the murky afterlife of the usual religions, but in technological and biological improvement” (Alexander, 51). This critic prefers „murky” divine redemption over „technological and biological improvement.” 
The Vatican similarly objects while making a much more subtle argument. In its recent study, Communion and Stewardship: Human Persons Created in the Image of God, the Vatican celebrates the "biogenetic characteristics" that apparently make each person unique at birth. This is the biogenetic character we have inherited, not one that we might design for the future.

Changing the genetic identity of man as a human person through the production of an infrahuman being is radically immoral. The use of genetic modification to yield a superhuman or being with essentially new spiritual faculties is unthinkable, given that the spiritual life principle of man - forming the matter into the body of the human person - is not a product of human hands and is not subject to genetic engineering. The uniqueness of each human person, in part constituted by his biogenetic characteristics and developed through nurture and growth, belongs intrinsically to him and cannot be instrumentalized in order to improve some of these characteristics. (Vatican, Communion and Stewardship, §91)

To change our inherited genetic identity is "radically immoral," says the Vatican (Communion and Stewardship). To change our "spiritual faculties is unthinkable." But upon this might one speculate that transhumanist scientists, who instrumentally alter our genome to create the posthuman, would be "radically immoral” if not „unthinkable”?

Does this indicate that traditionally religious people will be repelled by $\mathrm{H}+$ promises? No. At least not in every case (Green, 2015; Cole-Turner, 2015).

\section{Religious Transhumanism versus the Religion of Transhumanism}

The promise of human transformation into superintelligence combined with the promise of living forever has attracted the attention of religious believers. Like a bride to be, some classical believers have proposed a marriage between their respective religious tradition and transhumanism.

In his article, „What is Buddhist Transhumanism?” Michael LaTorra avows, „Buddhist transhumanism results from the meeting of these two 
streams [Buddhism and Transhumanism] and the formation of a common river flowing to a single sea, the summum bonum" (LaTorra, 229).

In his article, „What is Mormon Transhumanism?”, Lincoln Cannon avows, „Mormon transhumanism stands for the idea that humanity should learn how to be God" (Cannon, 203). Like adding salt to our entré, this Buddhist and this Mormon add transhumanism to their traditions to make a palatable if not delectable religious transhumanism.

But, I wonder if one needs to add religion to transhumanism to make it religious? Transhumanism is already religious. $\mathrm{H}+$ already provides an alternative worldview complete with a dogma regarding the purpose at work within evolution, a doctrine of technological progress leading to greater good, a trust in the salvific power of enhanced intelligence, and a utopian eschatology replete with a vision of the immortal posthuman. One does not need to add spiritual salt to this ocean water to make it taste salty. It's already salty.

Transhumanism, as a distinct form of modern culture, aspires to ultimacy and offers the promise of transformation, even utopian transformation. $\mathrm{H}+$ need not don itself with the clothes of a religious institution to be dubbed a spiritual community. „Culture is the form of religion, and religion is the substance of culture," Paul Tillich said repeatedly (Tillich, 3:158). The $\mathrm{H}+$ movement is an expression of modern techno-culture which makes ultimate claims. It is already religious. The question we must ask is this: is the religion of transhumanism a healthy religion? My diagnosis is worrisome. $\mathrm{H}+$ promises more than it can deliver. The ebullience of the transhumanist must be answered soberly by the public theologian who takes up the apologetic task.

\section{The Transhumanist and the Theologian}

Today's transhumanist feels no need to address any questions to the theologian. Perhaps because $\mathrm{H}+$ faith in technology has become a complete religion in itself. Through either AI or IA, $\mathrm{H}+$ promises transformation of our fragile bodies and inner minds. Through either RLE or cybernetic immortality, $\mathrm{H}+$ promises immortality. From the $\mathrm{H}+$ point of view, the 
theologian is an anachronism. Traditional religion has now been supplanted by a techno-faith that can actually deliver the equivalent of salvation. Well, that's the ebullient $\mathrm{H}+$ promise.

This is a moment for the theologian to recall St. Paul's advice to "discern what is the will of God--what is good and acceptable and perfect" (Romans 12:2). Perhaps the public theologian should ask: just what anthropology does transhumanism presuppose? Does the $\mathrm{H}^{+}$anthropology cohere with its soteriology? Posing these questions will uncover that $\mathrm{H}+$ is actually a form of Gnosticism. „Gnosticism may be defined as a system which taught the cosmic redemption of the spirit through knowledge," according to Patristics scholar Jaraslov Pelikan (Pelikan, 1:82).

A Gnostic anthropology presumes that human estrangement is due to ignorance, making knowledge the means of salvation. Whereas ancient Gnostics relied upon knowledge, today's transhumanists rely on intelligence, the capacity for knowledge. According to ancient Gnostics, we humans live in darkness, fallen from the realm of light. A smothered divine spark with partial knowledge within each of us awaits the Gnostic redeemer to enlighten us with expanded esoteric knowledge. According to today's transhumanists, the equivalent of the spark is human intelligence; and the equivalent of the Gnostic redeemer is the Singularity. Once we have been admitted to the domain of superintelligence, salvation and even immortality will have been obtained. Yes, we might say, $\mathrm{H}+$ anthropology and soteriology cohere with one another. But is this realistic? No.

The sober theologian will likely be troubled here. The $\mathrm{H}+$ vision is not realistic (Peters, 2010; 2018a; 2018b; 2018c). During New Testament times, the followers of Jesus sensed that something was askew in the Gnostic belief system. The fundamental reason for human estrangement is not ignorance, said the Christians. Rather, it is sin. Even when we humans have all the knowledge necessary, we can still decide to pursue evil. The human problem is in the will, not the mind. Gaining knowledge does not insure redemption from sin or rescue from evil. Nor would superintelligence redeem us from sin or rescue us from evil. If anything, advanced intelligence would only provide increased opportunity for perversion, exploitation, and violence. 
Roman Catholic theologian Brian Patrick Green discerns the problem internal to techno-soteriology. „Just as human intelligence is a powerful force, so too will AI be. Just as humans can apply their intelligence towards evil ends, finding ever newer and more fiendish ways to harm each other, so too will AI, at the bidding of its human masters" (Green, 2018, 8). Neither man-made machines nor whole brain emulations will provide escape from the human propensity to bend good things toward evil.

Christian anthropology attributes estrangement from God and neighbor to sin; and Christian soteriology includes forgiveness of sins accompanied by God's promise of resurrection from the dead. Salvation and transformation cannot be had without divine grace. The sin-and-grace dialectic is much more realistic than the Gnostic myth of redemption through enhanced knowledge. According to Reinhold Niebuhr, who lost faith in technological progress during an economic depression sandwiched between two world wars, the dialectic of sin-and-grace is more realistic than alternative ideologies regarding the human future.

"The issue of Biblical religion is not primarily the problem of how finite man can know God but how sinful man is to be reconciled to God and how history is to overcome the tragic consequences of its false eternals, its proud and premature efforts to escape finiteness." (Niebuhr 2:147) The Christian hope of consummation of life and history is less absurd than alternate doctrines which seek to comprehend and to effect the completion of life by some power or capacity inherent in man and his history. (Niebuhr, 2:298)

The public theologian should argue that sin-and-grace provides a much more realistic anthropology and a much more reliable soteriology.

Beware of the seductive enticement of a pseudo-salvation, warns Anglican D. Gareth Jones. ,The excesses of transhumanism with its picture of a new world order, in which medicine will be devoted to conquering mortality, overcoming ageing, vanquishing neurodegenerative diseases and enabling people to live to 600 or so years of age as healthy and fulfilled individuals, rightly repel Christians... These extreme vistas represent a rerun of the science-as-saviour mentality" (Jones, 14). In the hands of the transhumanist, science looks like a wolf in sheep's clothing. 
To belong to the biological species of Homo sapiens is plenty good enough. We were created by God this way, and we continue to be graced by this same God. With the God of grace as our redeemer, there is no need to climb the Tower of Babel on the ladder of intelligence amplification to become Homo deus.

\section{Conclusion}

This has been an exercise in public theology engaged in its apologetic task. I think of public theology as conceived in the church, reflected on critically in the academy, and meshed within the wider culture for the benefit of the wider culture (Peters, 2018d, 155). My mentor, David Tracy, directs the public theologian's gaze toward technology. „Public theologies partake of the call to hope and resistance in a modern period where the public realm is in danger of being fully technicized by the colonizing encroachments of the techno-economic realm" (Tracy, 19).

One self-assigned task of the public theologian is this: how do we de-colonize the hegemony that technology now enjoys in the global economy? This is important because transhumanism has upgraded technology into a religion replete with anthropology and soteriology. And minds overly invested in the $\mathrm{H}^{+}$promise may be drawn into a set of unrealistic expectations and frustrated hopes. Trusting our destiny to technological progress is like boarding a hot air balloon in a hurricane.

The Christian public theologian has learned from Scripture and history that the fundamental cause of human estrangement from God and neighbor is willful sin. It is not ignorance. It is not lack of intelligence. It is not lack of technology. No amount of artificial intelligence or even intelligence amplification can transform the human will. Only divine grace can.

The ebullient promises of the transhumanist should be greeted with applause for their vision of a healed and even utopian future. Yet, the sober theologian has the responsibility of reminding the human race about the fundamental problem of estrangement that has plagued our species since the darkness of our origin. We, just like our ancestors, find fiendish ways 
to exploit our knowledge for the service of exploitation, violence, and destruction. No technological enhancement can heal this rift. Only divine grace replete with forgiveness and the promise of resurrection can heal this estrangement.

\section{References}

Alexander, Brian, 2003. Rapture: How Biotech Became the New Religion. New York: Basic Books.

Barbour, Ian G., 1999. „Neuroscience, Artificial Intelligence, and Human Nature: Theological and Philosophical Reflections." Zygon 34:3 (September) 361-398.

Bostrom, Nick, 2019. „What is Transhumanism?” https://nickbostrom.com/tra/ values.html.

Brighter Brains Institute, 2019. https://brighterbrains.institute/.

Cannon, Lincoln. 2015. "What is Mormon Transhumanism?" Theology and Science 13:2 (May) 202-218.

Cole-Turner, Ronald. 2015. „Going Beyond the Human: Christians and Other Transhumanists." Theology and Science 13:2 (May) 150-161.

DeGrey, Aubrey. 2009. „Radical Life Extension: Technological Aspects.” Religion and the Implications of Radical Life Extension, eds., Derek F. Maher and Calvin Mercer. New York: Macmillan Palgrave; 13-24.

DeGrey, Aubrey. 2016. „Forever Young.” https://stemcellpodcast.com/ep-62-foreveryoung-featuring-dr-aubrey-de-grey.

Foerst, Anne (1998) „Cog, a Humanoid Robot, and the Question of the Image of God," Zygon 33:1 (March) 91-112.

Francis Fukuyama, Francis, 2004. “Transhumanism: The World's Most Dangerous Idea." Foreign Policy 144: 42-43.

Green, Brian Patrick. 2015. "Transhumanism and Roman Catholicism: Imagined and Real Tensions.” Theology and Science 13:2 (May) 187-201.

Green, Brian Patrick. 2018. „Ethical Reflections on Artificial Intelligence.” Science et Fides 6:2:1-23. http://apcz.umk.pl/czasopisma/index.php/SetF/article/view/ SetF.2018.015/15729.

Harari, Yuval Noah. 2017. Homo Deus: A Brief History of Tomorrow. New York: Harper. Herzfeld, Noreen L., 2002. In Our Image: Artificial Intellitgence and the Human Spirit. Minneapolis: Fortress Press.

Humanity +, 2018. https://humanityplus.org/.

Investopedia. 2018. https://www.investopedia.com/terms/a/artificial-intelligence-ai.asp. 
Istvan, Zoltan, 2019. “On the Issues.” http://www.ontheissues.org/Governor/Zoltan_Istvan_Principles_+_Values.htm.

Jones, D. Gareth, 2010. “A Christian Perspective on Human Enhancement," Science and Christian Belief 22:2: 14-16.

Kirkwood, Thomas B.L. 2008. “A systematic look at an old problem,” Nature 451: 7179: 644-647 (7 February ) 645.

Kull, Anne. 2016. „Cyborg or Religious? Technonature and Technoculture.” Science et Fides 4:1 (January) 295-311. http://apcz.umk.pl/czasopisma/index.php/SetF/ article/view/SetF.2016.016/8762.

Kurzweil, Ray, 2005. The Singularity is Near: When Humans Transcend Biology. New York: Penguin.

Kwon, Diana. 2018. „Self-Taught Robots,” Scientific American 318:3 (March ) 26-31. LaTorra, Michael, 2015. „What is Buddhist Transhumanism?” Theology and Science 13:2: 219-229.

Levy, Neil, 2016. “The Earthling's Secret Weapon: Cumulative Culture and the Singularity, Science, Religion and Culture 3:1: 19-30; file:///C:/Users/Ted/Downloads/1468597863SRC_3_1_19-30\%20(3).pdf.

Lynch, Michael Patrick. 2018. Cited by The Guardian, "Where is the boundary between your phone and your mind?” (December 9); https://www.theguardian. com/us-news/2018/dec/09/tech-mind-body-boundary-facebook-google?C$\mathrm{MP}=$ share btn_link $_{-}$

More, Max, 2005. “The Philosophy of Transhumanism,” http://media.johnwiley.com. au/product_data/excerpt/10/11183343/1118334310-109.pdf.

Niebuhr, Reinhold. 1941. The Nature and Destiny of Man, Gifford Lectures. 2 Volumes: New York, Scribners.

Pelikan, Jaroslav, 1971-1989. The Christian Tradition: A History of the Development of Doctrine. 5 Volumes: Chicago: University of Chicago Press.

Peters, Ted, 2009. "Afterword: Theological, Spiritual and Ethical Reflections on Radical Life Extension."Religion and the Implications of Radical Life Extension, edited by Derek Maher and Calvin Mercer. New York: Palgrave Macmillan; 155-168.

Peters, Ted, 2010. “Can We Enhance the Imago Dei?” Human Identity at the Intersection of Science, Technology, and Religion, edited by Nancey Murphy and Christopher C. Knight. Aldershot UK: Ashgate; 215-238.

Peters, Ted, 2011. "Transhumanism and the Post-Human Future: Will Technological Progress Get us There?" H+ Transhumanism and Its Critics, edited by William Grassie and Gregory Hansell. Philadelphia: Metanexus Institute; 147-175.

Peters, Ted, 2016. „Outer Space and Cyber Space: Meeting ETI in the Cloud,” International Journal of Astrobiology doi:10.1017/S1473550416000318 @ Cambridge University Press. 
Peters, Ted, 2018a. “Imago Dei, DNA, and the Transhuman Way” Theology and Science 16:3 (August), 353-362. https://doi.org/10.1080/14746700.2018.1488529.

Peters, Ted, 2018b. “Markers of Human Creaturehood: Soil, Spirit, and Salvation.” Science and Christian Belief 30:2:143-154.

Peters, Ted, 2018c. „Radical life extension, cybernetic immortality, and techno-salvation. Really?” Dialog 57:4 (December) https://doi.org/10. 1111/dial.12432.

Peters, Ted, 2018d. "Public Theology: Its Pastoral, Apologetic, Scientific, Political, and Prophetic Tasks," International Journal of Public Theology 12:2: 153-177; https://brill.com/abstract/journals/ijpt/12/1/ijpt.12.issue-1.xml.

Pryor, Adam, 2016. „Cyborg Bodies as the Subject of Ultimate Concern,” Bulletin of the North American Paul Tillich Society $42: 3$ (Summer 2016 ) 13-19; http://www. napts.org/assets/newsletters/NB423.pdf.

Russell, Stuart, 2016. “Should We Fear Supersmart Robots?” Scientific American 314:6 (June ) 58-59. http://www.scientificamerican.com/article/should-wefear-supersmart-robots/.

Singh, Sarwandt, 2017. "Transhumanism and the Future of Humanity: 7 Ways the World Will Change by 2030,” Forbes (November 20); https://www.forbes.com/ sites/sarwantsingh/2017/11/20/transhumanism-and-the-future-of-humanityseven-ways-the-world-will-change-by-2030/\#430a779a7d79

Tillich, Paul, 1951-1963. Systematic Theology. 3 Volumes: Chicago: University of Chicago Press.

Tirosch-Samuelson, Hava. 2018. "In Pursuit of Perfection: The Misguided Transhumanist Vision.” Theology and Science 16:2 (May) 200-223.

Tracy, David, 1994. On Naming the Present: God, Hermeneutics, and Church. Maryknoll NY and London: Orbis and SCM Press.

The Vatican: International Theological Commission, Congregation for the Doctrine of the Faith. 2015. Communion and Stewardship: Human Persons Created in the Image of God. http://www.vatican.va/roman_curia/congregations/cfaith/ cti_documents/re_con_cfaith_doc.

Vinge, Verner, 1992. „What is the Singularity,” https://mindstalk.net/vinge/vingesing.html.

Vita-More, Natasha. 2018. Transhumanism: What is it? Published by author.

Wertheim, Margaret, 1999. The Pearly Gates of Cyberspace: A History of Space from Dante to the Internet. New York: W.W. Norton.

Young, Simon. 2006. Designer Evolution: A Transhumanist Manifesto. Amherst, NY: Prometheus Books. 